\title{
PEMBANGUNAN EKONOMI ISLAM MELALUI PERAN SUMBER DAYA MANUSIA
}

\author{
Soritua Ahmad Ramdani Harahap, Muhammad Ulul Azmi dan Syamsuri \\ Universitas Darussalam Gontor \\ Email: ramdaniharahap688@gmail.com,muhammadululazmi@unida.gontor.ac.id dan \\ syamsuri@unida.gontor.ac.id
}

\begin{abstract}
Islam has complete rules in all aspects of human life, including economics. Muslim communities are asked to improve and develop all aspects of life, including economic and financial aspects. Therefore, the economic concept based on the Koran and al-Sunnah is a must in Islamic economic development. This study aims to analyze the development of the Islamic economy through human resources' role in the development of an Islamic economy. The research method uses qualitative methods and is analyzed descriptively. This study explains that Islamic economic development is closely related to the role of human resources in it. In presenting quality human resources, a religious foundation and expertise must be instilled. When two things have become a guideline, it will lead to and produce quality human resources.
\end{abstract}

Keywords: Development, Islamic Economic, and Human Resources.

\begin{abstract}
Abstrak
Islam memiliki aturan yang sangat lengkap dalam semua aspek kehidupan manusia termasuk dalam bidang ekonomi. Masyarakat Muslim diminta untuk dapat meningkatkan dan mengembangkan semua aspek kehidupan termasuk aspek ekonomi dan keuangan. Maka dari itu, konsep ekonomi didasarkan pada Al-Qur'an dan al-Sunnah menjadi hal yang wajib ada di dalam konsep pengembangan ekonomi Islam. Penelitian ini bertujuan untuk menganalisis perkembangan ekonomi Islam melalui peran sumber daya manusia dalam pengembangan ekonomi Islam. Metode penelitian menggunakan metode kualitatif dan di analisa secara deskriptif. Hasil penelitian ini menjelaskan bahwa pembangunan ekonomi Islam sangat berkaitan dengan peran sumber daya manusia di dalamnya. Dalam menghadirkan sumber daya manusia yang berkualitas maka harus ditanamkan sebuah dasar agama dan keahlian yang dimiliki. Ketika dua hal sudah menjadi pegangan maka akan bisa menuju dan menghasilkan para sumber daya manusia yang berkualitas.
\end{abstract}

Kata Kunci: Pembangunan, Ekonomi Islam, dan Sumber Daya Manusia. 


\section{PENDAHULUAN}

Islam telah mengatur seluruh apa yang ada di bumi ini, baik dalam aspek kehidupan manusia termasuk dalam bidang ekonomi. Agama Islam telah menganjurkan kepada umatnya untuk dapat mengoptimalkan segala potensi diri yang dimiliki dalam semua aspek kehidupan termasuk aspek dalam pembangunan di bidang ekonomi (Dimyati, 2017). Maka dari itu, konsep ekonomi harus berpedoman dengan al-Qur'an dan alSunnah. Hal inilah yang membedakan konsep pembangunan dalam Islam dengan konsep pembangunan dalam ekonomi konvensional yang lebih banyak diwarnai oleh pemikiran ekonom barat (Beik, 2016).

Salah satu aspek yang diutamakan dalam pembangunan ekonomi Islam adalah aspek sumber daya manusia. Keberhasilan dari suatu organisasi tergantung pada sumber daya manusia yang dimiliki, hal ini terkait dengan tanggung jawabnya dalam mengelola sumber daya yang ada dalam satu organisasi (Buyung, 2008). Islam sangat memperhatikan aspek sumber daya manusia dengan menjadikan manusia sebagai khalifah di muka bumi dan menjadi pihak utama yang mengelola sumber daya alam yang telah Allah ciptakan. Sebagaimana yang termaktub dalam surat al-Baqarah ayat 30:

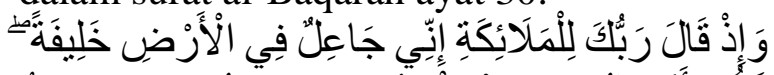

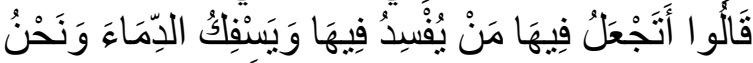

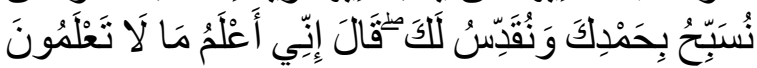

Dengan mengacu pada pengelolaan sumber daya alam maka sumber daya manusia merupakan bagian vital sebagai pelaku aktif dalam mengembangkan suatu organisasi. Sumber daya manusia yang berkualitas dan professional akan menjadikan sebuah organisasi dapat menjalankan setiap program dan aktivitasnya dengan baik (Fauzi \& Riyadi, 2015).

Sumber Daya Manusia (SDM) merupakan kekuatan terbesar dalam pengelolaan seluruh sumber daya yang ada dimuka bumi, karena pada dasarnya seluruh ciptaan Allah SWT sengaja diciptakan untuk kemaslahatan umat manusia. Dengan demikian, manusia sebagai pengguna sumber daya alam berkewajiban untuk menjaga, mengembangkan, dan memanfaatkannya dengan baik. Maka dari itu, apabila keadaan negara memiliki kelebihan sumber daya alam yang melimpah, belum tentu bisa menyejahterakan rakyatnya jika tidak memiliki kemampuan dalam memanfaatkan sumber daya manusianya. Namun Sebaliknya, walaupun keadaan negara yang kurang sumber daya alamnya tetapi bisa memanfaatkan sumber daya manusianya akan bisa menyejahterakan rakyatnya.

Di era modernisasi ini, sangat dibutuhkan lembaga yang turut andil dalam memberdayakan sumber daya manusia. Namun demikian, kebanyakan lembaga pemberdayaan SDM cenderung berkembang stagnan dan bahkan mundur dikarenakan kurangnya kepercayaan masyarakat kepada lembaga ini sehingga berpengaruh kepada peningkatan pemberdayaan SDM dan keuangan organisasinya. Berdasarkan penjelasan di atas, sumber daya manusia menjadi fokus utama dalam upaya mengembangkan ekonomi. Sumber daya manusia sebagai pelaku ekonomi harus memiliki bekal yang memumpuni agar kedepannya lembaga dan institusi yang dikelola dapat berkembang dengan baik.

\section{LITERATURE REVIEW}

Penelitian yang ditulis oleh Agung Eko Purwana tentang "Pembangunan dalam Perspektif Ekonomi Islam". Tulisan ini meneliti bagaimana perspektif Islam tentang pembangunan. Metode yang digunakan dengan menggunakan data kualitatif. Hasil dari tulisan ini untuk mencari isu kemiskinan, pengangguran, dan keadilan (Purwana, 2013). Penelitian ini mencari hasil untuk memecahkan masalah kemiskinan, pengangguran, dan pemetaan.

Selain itu, penelitian lainnya yang ditulis oleh Syamsuri tentang "Paradigma Pembangunan Ekonomi; Satu Analisis Kembali dari Perspektif Ekonomi Islam". Tulisan ini bertujuan untuk mengetahui tentang paradigma ekonomi Islam menurut 
perspektif Islam. Metode yang digunakan dalam penelitian ini dengan metode kualitatif (Syamsuri, 2016). Hasil dari penelitian ini adalah untuk mengetahui ukuran keberhasilan suatu perkembangan saat tuntutan kekhalifahan, dan Tazkiyah dapat memenuhi semua kebutuhan dasar setiap manusia dan pelestarian alam sekitar untuk jangka panjang yaitu generasi penerus. Paradigma pembangunan ekonomi liberal telah menjadi acuan konsep maupun teori ekonomi pembangunan di berbagai belahan dunia.

Selain itu, Syamsuri juga menulis tentang "Eksistensi dan Kontribusi Pondok Modern Darussalam Gontor Dalam Pembangunan Sumber Daya Manusia". Tulisan yang bertujuan untuk lebih memfokusan pada kontribusi pesantren Gontor dalam perkembangan ekonomi masyarakat berdasarkan sistem pembangunan ekonomi Islam. Metode yang digunakan adalah metode kualitatif. Hasil tulisan ini membahas pembangunan sumber manusia di pesantren bukan hanya sebatas pembekalan pengetahuan dan keterampilan saja, melainkan sebuah penekanan nilai-nilai moral, akhlak dan agama senantiasa menjadi perhatian utama di pesantren. Seperti penanaman aspek spiritual yang membangunkan jiwa manusia dengan pengalaman ibadah ritual maupun sosial (Syamsuri, 2016).

Penelitian lainnya dari tulisan Djaelany Haluty tentang "Islam dan Manajemen Sumber Daya Manusia Yang Berkualitas" (Haluty, 2014). Tulisan ini memiliki sebuah tujuan yang berbeda dengan penelitian terdahulu. Fokus pembahasan ditujukan untuk menjelaskan arti penting manusia dalam pembangunan ekonomi yang dilihat dari perspektif Islam. Metode yang digunakan adalah dengan metode analisis deskriptif yang menjelaskan sumber daya manusia menurut Islam beserta potensi besarnya.

\section{METODE PENELITIAN}

Metode penelitian yang penulis gunakan dalam penelitian ini adalah dengan menggunakan metode studi pustaka, dimana dalam penelitian yang dilakukan ini dengan membaca serta melakukan berbagai hal terutama mempelajari berbagai literaturliteratur yang ada (Sugiyono, 2014). Literatur yang dimaksud adalah sumber yang mana memiliki hubungan dengan permasalahan penelitian. Dengan memahami literatur tersebut, akan dapat memahami tujuan dari masalah yang ingin diselesaikan. Dengan memahami literatur tersebut, akan dapat memahami tujuan dari masalah yang ingin diselesaikan. Pendekatan penelitian dilakukan dengan mengacu pada konsep pembangunan ekonomi dalam Islam yang menjadi landasan penelitian.

Adapun metode penelitian dilakukan dengan menggunakan instrumen pengumpulan data. Pengumpulan data dalam penelitian literatur dilakukan dengan mengumpulkan data-data kepustakaan (Harahap, 2014): Pertama, pengumpulan karya-karya tokoh yang membahas mengenai topik yang sedang diteliti sebagai sebuah data primer. Kemudian dibaca dan ditelusuri karya-karya lain yang dihasilkan tokoh itu mengenai bidang lain. Kedua, ditelusuri melalui karya-karya orang lain mengenai masalah yang bersangkutan atau topik yang sedang diteliti sebagai sebuah data sekunder.

Setelah melakukan pengumpulan data, maka selanjutnya data akan dianalisis dengan beberapa cara, diantaranya adalah: Interpretasi yaitu upaya tercapainya pemahaman yang benar terhadap fakta data dan gejala. Koherensi: agar pembahasan dapat dipahami secara tepat maka seluruh konsep tentang konsumsi dilihat menurut keselarasannya antara satu pembahasan dengan pembahasan lainnya. Heuristika: berdasarkan bahan-bahan baru, metodologi baru, maka peneliti berusaha untuk menemukan sebuah pemahaman baru (Harahap, 2014). 


\section{KONSEP DASAR}

\section{Definisi Pembangunan Ekonomi Islam}

Pembangunan ekonomi dilihat dari meningkatnya produktivitas ekonomi secara keseluruhan mulai dari para pekerja rata-rata dan juga meningkatnya perbandingan antara pendapatan dengan jumlah total penduduk. Hal ini merupakan proses yang dinamis dan struktural yang akan menghasilkan perbaikan tampilan ekonomi secara berkelanjutan, fakta dan potensial (Fadlan, 2010). Pada umumnya orang beranggapan bahwa pembangunan adalah kata benda netral yang maksudnya adalah suatu kata yang digunakan untuk menjelaskan proses dan usaha untuk meningkatkan kehidupan ekonomi, politik, budaya, infrastruktur masyarakat, dan sebagainya (Purwana, 2013). Pelaksanaan pembangunan ekonomi pada realisasinya perlu membangkitkan peran masyarakat dengan tujuan peningkatan pendapatan penduduk, turunnya jumlah pengangguran, dan mengurangnya tingkat kemiskinan.

Di sisi lain, konsep pembangunan ekonomi dalam Islam bersifat komprehensif dan sinergis, yaitu pembangunan yang meliputi pengembangan moral, spiritualitas dan material (Asmuni, 2003). Aspek moral, spiritualitas, material, sosial dan ekonomi tidak boleh lepas untuk mencapai perkembangan ekonomi yang menjadikan maslahat dalam Islam. Pembangunan ekonomi ditentukan oleh sumber daya manusia yang berkualitas dalam mengelola sumber daya alam yang tersedia (Nurul Huda, et al., 2015). Selain itu, pembangunan tercipta dari golongan masyarakat kreatif, yang akan bertindak sebagai pencipta perubahan-perubahan.

Secara istilah pembangunan berasal dari kalimat bangun; bangkit, terdiri dari kata derivasi dari bangun yaitu membangun atau pembangunan yang berarti membina, membuat, mendirikan, memperbaiki; membuat supaya maju dan berkembang (Syamsuri, 2018). Sebagaimana firman Allah swt yang tertulis dalam surah Hud ayat 61 .

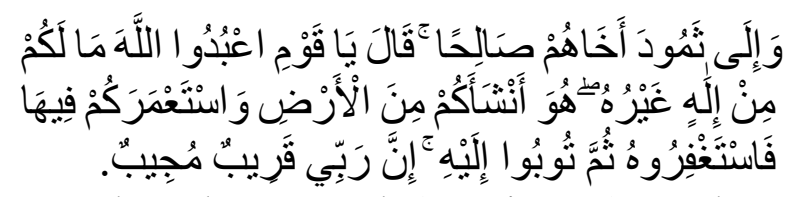

Dan kepada Tsamud (Kami utus) saudara mereka Shaleh. Shaleh berkata: "Hai kaumku, sembahlah Allah, sekali-kali tidak ada bagimu Tuhan selain Dia. Dia telah menciptakan kamu dari bumi (tanah) dan menjadikan kamu pemakmurnya, karena itu mohonlah ampunan-Nya, kemudian bertobatlah kepada-Nya, Sesungguhnya Tuhanku amat dekat (rahmat-Nya) lagi memperkenankan (do'a hamba-Nya)".

Ekonomi Pembangunan Islam juga memiliki sebuah falsafah, konsep, dan teori yang berbeda dengan teori dan model pembangunan barat. Oleh karena itu, Pembangunan ekonomi Islam menuntut manusia untuk menuju ke arah keseimbangan antara kebahagiaan di dunia dan juga di akhirat, keadilan antara hak individu dan masyarakat, membina suatu keharmonisan antara individu dan masyarakat, menjaga kelestarian alam sekitar dari sebuah kerusakan dan kedzholiman (Syamsuri, 2018). Dengan hal ini, maka Islam dengan jelas mengatur bagaimana umatnya harus bisa melakukan suatu kegiatan berlandaskan sumber utama umat Islam yaitu al-Qur'an dan hadist.

Di tengah kegagalan praktek pembangunan yang berlandaskan pada sistem kapitalis ini, terlihatlah sebuah alternatif sistem ekonomi yang berbasiskan pada nilai-nilai Islam. Pada saat krisis ekonomi moneter yangmelanda dunia, lembaga-lembaga ekonomi di negara-negara berkembang yang menerapkan mekanisme syariah terbukti dapat bertahan dan bahkan mampu untuk tumbuh dan berkembang (Purwana, 2013). Dalam beberapa teori ekonomi, nilai-nilai yang ditawarkan ekonomi Islam tergolong hal yang baru. Meskipun pada kenyataannya ajaran Islam telah memberikan petunjuk-petunjuknya dalam melakukan aktivitas berekonomi semenjak dari zaman rasul, akan tetapi secara bangunan ilmu masih membutuhkan 
berbagai macam proses untuk menjadi baik dan tepat untuk diterapkan.

Muncul dan berkembangnya ilmu ekonomi Islam ini turut memberikan alternatif pemecahan masalah yang berlarutlarut akibat dari kejamnya sistem kapitaslisme (Purwana, 2013). Manusia diberikan tugas sebagai khalifah dan juga sebagai unsur pelaku dalam proses pembangunan ekonomi. Oleh karena itu, setiap individu diwajibkan memiliki nilainilai keagamaan yang tinggi yang mana dapat mendukung proses pembangunan. Dengan berpegang pada nilai-nilai keagamaan, diharapkan sumber daya manusia dapat menjalankan perannya sebagai unsur pelaku yang menggerakkan pembangunan dan sebaliknya ketika peran ini tidak dipergunakan dengan baik maka akan menghambat proses pembangunan ekonomi (Asmuni, 2003).

Pada hakikatnya pembangunan dilaksanakan oleh suatu negara dengan tujuan peningkatan kesejahteraan dan kebahagiaan manusia di dunia maupun akhirat. Pembangunan tidak hanya ditujukan untuk kepentingan materi semata tapi juga harus dihubungkan dengan kepentingan yang lebih abadi yaitu akhirat (Purwana, 2013). Oleh karenanya, pembangunan harus merujuk atau didasarkan pada ketentuan dalam syariat islam baik yang telah dituliskan dalam Al-Quran maupun Hadist. Dalam Islam, pembangunan sumber daya manusia secara lengkap telah menjadi target pertama dalam pandangan ekonomi Islam. Selain itu, pembangunan tidak hanya sebatas untuk membangun ekonomi rakyat semata, melainkan lebih kepada pembangunan mental seseorang (Purwana, 2013).

\section{Sumber Daya Manusia dalam Islam}

Manusia diciptakan sebagai penerima dan pelaksana syariah oleh Allah sehingga mereka ditempatkan pada kedudukan yang mulia daripada makhluk lainnya. Untuk mempertahankan kedudukan yang mulia ini, Allah melengkapi manusia dengan akal dan perasaan yang memungkinkan baginya untuk menerima dan mengembangkan ilmu pengetahuan dan membudayakan ilmu yang dimiliki. Hal ini bermakna bahwa kedudukan manusia sebagai makhluk mulia dikarenakan akal, perasaaan, dan seluruh ilmu pengetahuan yang dikaitkan dengan pengabdian kepada sang Pencipta (Daradjat, 1996).

Potensi-potensi yang diberikan oleh Allah pada dasarnya merupakan petunjuk (hidayah) yang diperuntukkan bagi manusia agar dapat menentukan sikap hidup yang serasi dengan hakikat penciptaannya (Jalaluddin, 1996). Hasan Langgulung berpendapat bahwa potensi yang terdapat pada manusia sangat penting sebagai karunia yang diberikan Allah untuk menjalankan tugas kekhalifahannya di muka bumi ini. Suatu kedudukan yang sangat istimewa di alam semesta ini. Manusia tidak akan dapat mengemban amanah sebagai khalifah jikalau tidak dilengkapi dengan potensi-potensi tersebut dan mengembangkannya sebagai suatu kekuatan (Langgulung, 1995), yang berarti Sumber Daya Manusia yang berkualitas adalah mereka yang dapat memper-tanggungjawabkan amanahnya sebagai khalifah yang baik di bumi.

Semula SDM merupakan bentuk terjemahan dari "human resource" namun adapula ahli yang menyamakan istilah ini dengan "man power" (tenaga kerja). Dan bahkan sebagian yang lain menyetarakan pengertian sumber daya manusia dengan (personalia, kepegawaian, dan sebagainya) (Sutrisno, 2009). Werther dan Davis menyatakan bahwa "sumber daya manusia adalah pegawai yang siap, mampu dan siaga dalam mencapai tujuan-tujuan organisasi”. Sedangkan sumber daya manusia yang berkualitas adalah yang mampu menciptakan bukan hanya nilai komparatif tetapi juga nilai kompetitif-generatif-inovatif dengan memanfaatkan energy tertinggi seperti: intelligence, creativity, dan imagination (Sutrisno, 2009).

Kualitas SDM sendiri tentu saja tidak cukup hanya dengan menguasai ilmu pengetahuan dan teknologi (IPTEK), tetapi 
juga pengembangan nilai-nilai rohani spiritual, yang berupa iman dan taqwa (IMTAQ). SDM yang tidak disertai dengan iman dan taqwa hanya akan membawa manusia ke arah ketamakan nikmat duniawi atau hedonisme belaka, yang kedepannya akan memacu pada eksploitasi alam sebesarbesarnya tanpa rasa tanggung jawab dan bahkan penindasan terhadap sesama manusia (Wakhudin, 1998). Dengan demikian Sumber Daya Manusia dalam pandangan Islam adalah manusia yang memiliki akhlak mulia yang senantiasa menyembah Allah dan menebarkan kebaikan di alam semesta ini serta bertaqwa pada Allah.

\section{PEMBAHASAN DAN DISKUSI Pembangunan Sumber Daya Manusia Islami}

Islam adalah agama yang mengandung usaha, perjuangan dan gerakan menuju perubahan sosial (Nur Chamid, 2010). Unsur-unsur pembangunan dalam Islam menuju perubahan sosial yang sehat sebagaimana yang di inginkan oleh ajaran agama Islam sendiri. Tugas tersebut mencakup pada hal atau unsur kepemimpinan, ekonomi intelektual dan politik Islam yang tinggi. Tujuan dari semua ini adalah untuk merumuskan arahan dan strategi serta cara mencapainya. Pada saat yang sama membangun institusi dan merancang proses yang bisa dijadikan kebijakan selanjutnya. Itulah sebagian isu pemikiran dalam rangka mengislamkan pembangunan. Ada beberapa cara dalam proses pembangunan sumber daya manusia, yang mana tersusun atas 4 langkah sebagai berikut (Nawawi, 1997):

1. Merancang kebutuhan akan sumber daya manusia yang akan datang

2. Memproyekkan persediaan sumber daya manusia yang akan datang

3. Merencanakan kebijaksanaankebijaksanaan dan program-program untuk memenuhi semua kebutuhan akan sumber daya manusia.

4. Menilai keefektifan pembangunan sumber daya manusia
Dalam penjelasan lain, Hadari Nawawi menyatakan bahwa program pengembangan personil sumber daya manusia meliputi aspek yang cukup luas antara lain mengenai sebuah peningkatan kemampuan kerjanya, peningkatan dedikasi, moral dan disiplin kerja serta adanya pengarahan dan pembentukan motif kerja yang objektif. Pengembangan sumber daya manusia dapat ditempuh dengan melalui berbagai cara (Nawawi, 1997). Salah satu di antaranya adalah dengan melalui kegiatan pelatihan (training). Melalui kegiatan pelatihan, sumber daya manusia tersebut dapat didayagunakan oleh organisasinya semaksimal mungkin.

Sumber daya manusia merupakan sebuah terjemahan dari bahasa inggris yaitu human resources, namun ada beberapa ahli atau pakar yang menyamakan sumber daya manusia sebagai tenaga kerja (Sutrisno, 2009). Selain itu, ada sebagian lain yang menyamakannya dengan man poweryang berarti bahwa pengertian sumber daya manusia sama dengan personal. Sedangkan menurut Abdurrahmat fatoni menyatakan sebuah makna yang terpisah menjadi 4 suku kata yaitu manajemen, sumber, daya, manusia (Fatoni, 2006). Sumber daya manusia yang menjadikan manusia sebagai sumber daya yang optimal dalam suatu pembangunan.

Adapun dasar dalam filosofis ekonomi Islam menyatakan bahwa fungsi sumber daya manusia baik dalam konteks individu ataupun anggota masyarakat adalah sebagai khalifah Allah di muka bumi (Nurul Huda, et al., 2015). Inilah kelebihan konsep pembangunan Islam dari konsep-konsep lainnya, dengan menempatkan peran manusia pada tempat yang paling tinggi dan sangat terhormat, tetapi juga memiliki tanggung jawab dalam setiap apa yang dilakukan. Sumber daya manusia adalah khalifah Allah di muka bumi untuk memakmurkan bumi dan bertanggung jawab kepada Allah tentang pengelolaan sumber daya yang telah diamanahkan kepadanya (Salleh, 2012). 
Sumber daya manusia, baik pada aspek kualitas maupun kuantitas memang sangat diperlukan untuk dapat menentukan kinerja seseorang, produktifitas dan keberhasilan suatu institusi. Dalam menuju sumber daya manusia yang berkualitas maka diperlukan 5 kriteria utama, diantaranya (Ghozali, 2018):

1. Shidiq, artinya memiliki kejujuran dan selalu melandasi ucapan keyakinan,serta perbuatan berdasarkan ajaran islam.

2. Istiqomah, artinya konsisten dalam iman dan nilai-nilai yang baik meskipun menghadapai tantangan dan godaan.

3. Fatanah artinya mengerti, memahami, dan menghayati secara mendalam segala tugas dan kewajiban.

4. Amanah artinya memiliki tanggung jawab menjalankan kewajiban.

5. Tabligh artinya mengajak sekaligus menjadi uswah.

Sumber daya manusia merupakan sebuah modal dasar pembangunan nasional (Steffeny, 2013). Oleh karena itu, kualitas sumber daya manusia senantiasa harus dikembangkan dan diarahkan agar bisa mencapai tujuan yang diharapkan. Berbicara mengenai sumber daya manusia sebenarnya dapat dilihat dari dua aspek yaitu kualitas dan kuantitas (Syamsuri, 2016). Sumber daya manusia haruslah berperan ganda, baik dia sebagai objek maupun sebagai subjek pembangunan. Sebagai objek suatu pembangunan, sumber daya manusia merupakan sasaran pembangunan mendapatkan hak kesejahteraan, sedangkan sebagai subjek pembangunan, sumber daya manusia berperan penting sebagai pelaku pembangunan yang sangat menentukan kemajuan sebuah program. Pada dasarnya, manusia diciptakan untuk mampu berinteraksi dengan baik dalam bermasyarakat, dan saling tolong menolong dalam memenuhi kebutuhan hidupnya.

Sumber daya manusia yang handal dalam pembangunan dapat dilihat dari kualitasnya yang tinggi. Dalam hal ini, sumber daya manusia dalam pembangunan memiliki peranan penting dalam kaitannya untuk dapat meningkatkan kualitas pembangunan dan menjaga keberlangsungan pembangunan itu sendiri. Sementara itu, sistem pendidikan yang lebih mengedepankan sifat materialistic terbukti telah gagal melahirkan output sumber daya manusia yang menguasi iptek yang sekaligus berdaya saing tinggi (Kurniawan, 2015). Pengembangan sebuah ilmu harus tetap dibatasi dengan nilai-nilai agama, agar para murid dapat mengembangkan ilmu-ilmu secara bebas namun tetap selalu memegang teguh nilai-nilai agama.

Maka dari itu, Islam hadir sebagai agama sekaligus pandangan hidup yang sempurna yakni rahmatan lil 'alamin, jelas tidak mengenal konsep pemisahan antara urusan ritual dan urusan duniawi(Rasyid, 2016). Sholat merupakan ibadah yang merupakan bagian dari syariat dimana seluruh umat Islam harus terikat sebagaimana keterikatan kaum muslimin pada syariat dibidang lain, seperti ekonomi, sosial dan politik. Pada intinya, seluruh aktivitas seorang Muslim adalah ibadah yang bertujuan mencapai kebahagiaan dunia dan juga akhirat (falah).

\section{Solusi Dalam Pembangunan Sumber Daya Manusia}

Sumber daya manusia menjadi penentu yang paling penting dalam pembangunan ekonomi, hal ini dikarenakan manusia merupakan subjek utama sebagai agen dalam pembangunan yang dituntut agar mampu mengelola sumber daya alam, membina dan menggerakan institusi sosial, ekonomi dan politik serta mengaktifkan proses pembangunan itu sendiri (Syamsuri, 2018). Maka dari itu, ada beberapa pendapat yang membagi maksud manusia itu sendiri (Sutrisno, 2009), yaitu :

1. Manusia sebagai sumber pengelola

2. Dengan energi yang tersimpan dalam ototnya, manusia dapat bekerja dalam berbagai macam bidang, antara lain: bidang perindustrian, sarana transportasi, perkebunan, perikanan, perhutanan, pertanian, dan peternakan. 
3. Manusia sebagai pelestarian

4. Kemampuan berpikir manusia merupakan suatu faktor yang sangat penting bagi sumber daya alam, karena berfikir merupakan landasan utama bagi seorang manusia. Manusia sebagai makhluk hidup yang sempurna dengan akalnya, harus mampu mengolah sumber daya alam untuk kepentingan hidup bermasyarakat dan mampu mengubah keadaan sumber daya alam melalui ilmu dan teknologinya.

Pada era saat ini, tenaga kerja manusia menghadapi tantangan yang semakin berat. Perkembangan ilmu dan teknologi sangat pesat dan manusia dituntut untuk memiliki spesialisasi dan keahlian tertentu untuk selalu dapat bersaing.Pada saat ini, manusia makin terkotak-kotak oleh aturan teknis yang menghalangi dirinya untuk berkreasi dan berinovasi. Dalam beberapa masa yang akan datang,ilmu pengetahuan dan teknologi akan mengganti peranan manusia sebagai pekerja dan individu yang utuh, karena pekerjaan rutin manusia akan dikerjakan oleh mesin yang cara kerjanya dianggap lebih teliti, lebih efektif, efisien, dan lebih berani (Agustin, 2010).

Selain itu, ada empat hal yang juga termasuk dalam penilaian sumber daya manusia dalam melakukan pekerjaannya. Penilaian kinerja sumber daya manusia dalam pandangan Islam dipengaruhi terhadap perkembangan masyarakat terutama pada budaya dan nilai-nilai sosial (Social values). Sudah seharusnya manajemen syariah didasarkan pada hal-hal yang mengandung nilai-nilai Islami. Dalam mencapai sumber daya manusia yang berkualitas mencakup empat hal (Yusuf, 2016), yaitu:

1. Sumber daya manusia harus memiliki nilai-nilai dan akhlak Islami, diantaranya adalah tauhid, adil, siddiq, amanah, fathanah, dan tabligh. Nilai-nilai diatas merupakan sifat yang harus diterapkan umat Islam.

2. Kompensasi dan penekanan terpenuhinya kebutuhan dasar sumber daya manusia.
3. Faktor kemanusiaan dan spiritual.

4. Sistem dan struktur organisasi (Ukhuwah Islamiyah), dimana pimpinan harus dekat dengan bawahan. Kedekatan pimpinan dan bawahan dalam ukhuwah Islamiyah, tidak berarti akan menghilangkan otoritas formal dan ketaatan bawahan pada atasan selama kedekatan itu tidak mengandung dosa.

Manusia memiliki fakor penting dalam pembangunan, dan manusia diharapkan mampu memainkan perannya dengan aktif (Haluty, 2014). Manusia juga wajib untuk memanfaatkan apa yang bisa ia manfaatkan dari sumber daya alam dengan tidak berbuat keborosan dalam kehidupannya, baik orang mampu ataupun tidak. Hal ini ditujukan untuk memperbaiki taraf kehidupan manusia itu sendiri menuju kearah kebaikan moral, ekonomi, dan sosial mereka. Untuk mencapai solusi pembangunan sumber daya manusia yang maksimal ada beberapa hal yang harus dilalui oleh setiap manusia (Yusuf, 2016), antara lain:

1. Mengubah sebuah tantangan menjadi sebuah kesempatan

Bagi mereka yang belum siap atau bahkan takut akan cepatnya arus globalisasi merupakan sebuah ancaman yang menakutkan dan globalisasi akan membuatnya semakin jauh terbelakang. Untuk menghadapi tantangan tersebut, semua umat Islam perlu mempunyai beberapa persiapan, yaitu: mengubah sebuah mindset untuk siap bertarung dalam arus globalisasi.

2. Mengubah Sikap Mental

Kondisi umat Islam saat ini sedang mengalami keterpurukan terhadap mentalitas, terutama ketika menghadapi permasalahan ekonomi dan politik. Mengubah sikap mental mulai dari sikap, kesadaran dan kesanggupan diri untuk menghadapi perubahan hanyadapat dilakukan oleh umat Islam sendiri untuk siap dan berbekal pada zaman ini. 


\section{KESIMPULAN}

Sumber daya manusia menjadi faktor utama dalam pembangunan ekonomi di setiap tempat. Ketika sumber daya manusia yang dimiliki memiliki sifat yang baik dan berkualitas, maka akan dapat meningkatkan lembaga/organisasi yang sedang dikelolanya. Islam sangat memperhatikan segala bentuk aktivitas manusia, semua yang dilakukan oleh umat manusia harus selalu berlandaskan dengan al-Qur'an dan al-Hadist. Hal ini yang menjadikan manusia takut akan berbuat salah dan selalu melakukan kebaikan dalam hidupnya. Semua kendala yang terjadi pada lembaga/organisasi diantaranya disebabkan oleh sumber daya manusia yang kurang baik atau belum maksimal. Dengan memiliki dasar dan pengalaman yang baik serta berpegang pada nilai-nilai agama diharapkan sumber daya manusia lebih bertanggungjawab akan amanah yang diembannya dan mampu menjadi sumber daya manusia yang berkualitas.

\section{DAFTAR PUSTAKA}

Al-Mizan. (2016). "Pembangunan Ekonomi Dalam Perspektif Ekonomi Islam". Maqdis: Jurnal Kajian Ekonomi Islam, (1)2, Juli-Desember.

Agustin, Sri. (2010). "Tantangan Pengembangan Sumber Daya Manusia Indonesia Di Era Global”, Jurnal Jurusan Pendidikan Geografi FIS UNY.

Amaliah, Ima. 2013. "Pengaruh Nilai Islam Terhadap Kinerja Kerja”, Jurnal MIMBAR, (29)2, Desember.

Arief, Mohammad. (2010). "Spiritual Manajemen: Sebuah Refleksi Dari Pengembangan Ilmu Manajemen", Jurnal Ekonomi Modernisasi, (6), Juni.

Asmuni. (2003). "Konsep Pembangunan Ekonomi Islam", Jurnal AlMawaridi, Edisi X.

Asnaini. (2008). "Pengembangan Mutu SDM Perbankan Syari'ah: Sebagai Upaya Pengembangan Ekonomi Islam", Jurnal La_Riba, (2)1.
Beik, Irfan Syauqi. (2016). Ekonomi Pembangunan Syariah. Jakarta: PT. Raja Grafindo.

Buyung, Imron. (2008). "Strategi Pengembangan Sumber Daya Manusia Di Pondok Pesantren Bahrul Ulum Tambak Beras Jombang Jawa Timur". Skrpsi. Yogyakarta: Fakultas Dakwah Universitas Islam Negeri Sunan Kalijaga Yogyakarta.

Chamid, Nur, MM. (2010). Sejarah Pemikiran Ekonomi Islam. Yogyakarta: Pustaka Pelajar.

Daradjat, Zakiah. (1996). Ilmu Pendidikan Islam. Jakarta: Bumi Aksara.

Departemen Agama RI. (2009). Al-Qur'an dan Terjemahnya. Bandung: PT Sygma Examedia Arkanlema.

Dimyati. (2017). "Paradigma baru ekonomi Islam", La_Riba Jurnal Ekonomi Islam, (1)2, Desember.

Fadlan. (2010). Konsep Pembangunan Ekonomi Berbasis Islam, Al-Ahkam, (5)2, Desember.

Fathoni, Abdurrahmat. (2006). Manajemen Sumber Daya Manusia. Jakarta: PT. Rieneka Cipta.

Ghozali, Mohammad. (2018). Kewirausahaan Syariah, Ponorogo: Unida Gontor Press.

Haluty, Djaelany. (2014). "Islam dan Manajemen Sumber Daya Manusia Yang Berkualitas", Jurnal Irfani, (10)1, Juni.

Huda, Nurul, et al. (2015). Ekonomi Pembangunan Islam. Jakarta: Prenada Media Group.

Jalaluddin. (1996). Filsafat Pendidikan Islam, Jakarta: Raja Grafindo Persada.

Kurniawan, Sugeng. (2015). “Konsep Manajemen Pendidikan Islam Perspektif al-Qur'an dan al-Hadits", Nur El-Islam, (2)2, Oktober.

Langgulung, Hasan. (1995). Manusia dan Pendidikan: Suatu Analisa Psikologi dan Pendidikan. Jakarta: Pustaka alHusna. 
Nawawi, Hadari. (1997). Administrasi Pendidikan. Jakarta: Gunung Agung.

Purwana, Agung, Eko. (2013). Pembangunan Dalam Perspektif Ekonomi Islam, Justitia Islamica, (10)1, Jan-Juni.

Rasyid, Muhammad, Makmun. (2016). "Islam Rahmatan Lil Alamin Perspektif Kh. Hasyim Muzadi”, Epistemé (11)1, Juni.

Sutrisno, Edy. (2009). Manajemen Sumber Daya Manusia, Jakarta: Kencana Prenada Media Group.

Syamsuri. (2016). "Paradigma Pembangunan Ekonomi; Satu Analisis Tinjauan Ulang dari Perspektif Ekonomi Islam", Islamic economic: Jurnal Ekonomi Islam, (7)2, Desember.

Syamsuri. (2016). "Eksistensi dan Kontribusi Pondok Modern Darussalam Gontor Dalam Pembangunan Sumber Daya Manusia", Jurnal Ta'dib, (11)2, Desember.

Syamsuri. (2018). Ekonomi Pembangunan Islam. Ponorogo: Unida Gontor Press.

Steffenny. (2013). “Analisis Penerapan Human Resource Training and Development Efektivitasnya pada PT. Jaya Mas Mandiri Plus Surabaya", Agora, (1)3, Juni.

Wakhudin. (1998). Tarmizi Taher, Jembatan Umat, Ulama, dan Umara. Bandung: Granesia,

Yusuf, Burhanuddin. (2016). Manajemen Sumber Daya Manusia di Lembaga Keuangan Syariah. Jakarta: Rajawali Pers. 